\title{
Patryk Lewandowski
}

mgr inż.

Wydział Budownictwa Lądowego i Wodnego Politechniki Wrocławskiej

Katedra Geotechniki, Hydrotechniki, Budownictwa Podziemnego i Wodnego

patryk.lewandowski@pwr.edu.pl

DOI: $10.35117 /$ A_ENG_17_08_07

\section{The problem of degrading public road categories in the light of the Public Roads Act}

\begin{abstract}
The article contains information about the Public Roads Act, as well as problems encountered by local authorities in application of the Act based on resolutions adopted by the Regional Assembly of the Dolnośląskie province and court rulings connected with the degrading of provincial roads, which have been passed after the amended Act has entered into force. We also presented the possible steps that could be undertaken by local authorities to assure proper performance of the "cascade" act.
\end{abstract}

Keywords: "Cascade" act; Road categories; Public roads

\section{Introduction}

The aim of the article is to familiarize readers with the subject of the amended Act on public roads, called cascading act. The article contains information about the content of the Act, as well as problems encountered by local government authorities when applying it on the basis of adopted resolutions of the Dolnośląskie Regional Assembly and court judgments related to depriving the category of provincial roads, which were announced after the amended act came into force. It also presents possible steps that may be taken by local government authorities in order to ensure the correct implementation of the cascading act.

\section{General description of the amended law on transfer of roads}

The so-called cascade act was passed on 13/09/2013, but due to appeal to the Constitutional Tribunal it did not enter into force until 24/06/2015. Then, after a positive sentence, she was signed by the president and became applicable. The text of the amendment focuses on the legal process that must be carried out to deprive a given public road of the category and pass it to the lower self-governing body. The cascading act says that when a new section of the national road, which replaces the old section, is built, it is automatically categorized as a section of the provincial road.

The Provincial Council may, but not necessarily, deprive the category of a road with a proportional length to the adopted section. There is no limit in which the Council can do so. In other words, the road that is to be passed below in hierarchy may be located in another district and commune than the accepted old roads in the National Roads network. The only requirement set by the law for self-government authorities is the need to inform the district management board for 30 days before passing a resolution depriving a given section of road.

The cascade principle also applies to districts, which may also transfer a proportional section of the road to the section from the Provincial Council pursuant to the Act. The Council is obliged to inform the commune authorities 30 days before the resolution of the County Council depriving the selected section of the district road.

The commune authorities cannot deprive the category of road sections that were transferred to them by higher self-government bodies, pursuant to the Act. It should also be noted that local government bodies may also transfer a section get from other local 
government authorities, as long as the received section does not meet the definition of a given route category.

\section{Causes of problems in implementing the amended Public Roads Act}

Although the text of the resolution is quite simple and does not have entries difficult in interpretation, there are various problems with depriving the category of public roads. The flagship example of unsuccessful deprivation of the road category is the resolution No. XVI / 428/15 of November 26, 2015, in which the Lower Silesian regional council deprives the entire range of road sections of the category. The Jeleniogórski District appealed against the resolution to the provincial administrative court, which in its judgment No. III SA / Wr 359/16 - Judgment of the Provincial Administrative Court in Wrocław of 23.06.2016 overturned the appealed resolution. In the justification of the verdict, we can read that in the challenged resolution there is no clear information on the implementation of the requirements imposed by the act, no information about the fact that districts were informed in the required time, and most importantly, there was no justification that the sections of roads that the province wants hand over to the district no longer meet the definitions of provincial roads. Indeed, when we look at the content of the challenged resolution, we can see very poor and only general descriptions. The entire resolution consists only of the cited points of the act, the contractor of the resolution, and the date on which the resolution comes into force. In the second part you will find only attachments, in which the road sections were saved and to whom they are transferred (see Table 1).

Tab.1. Contested annex to the resolution No. XVI / 428/15

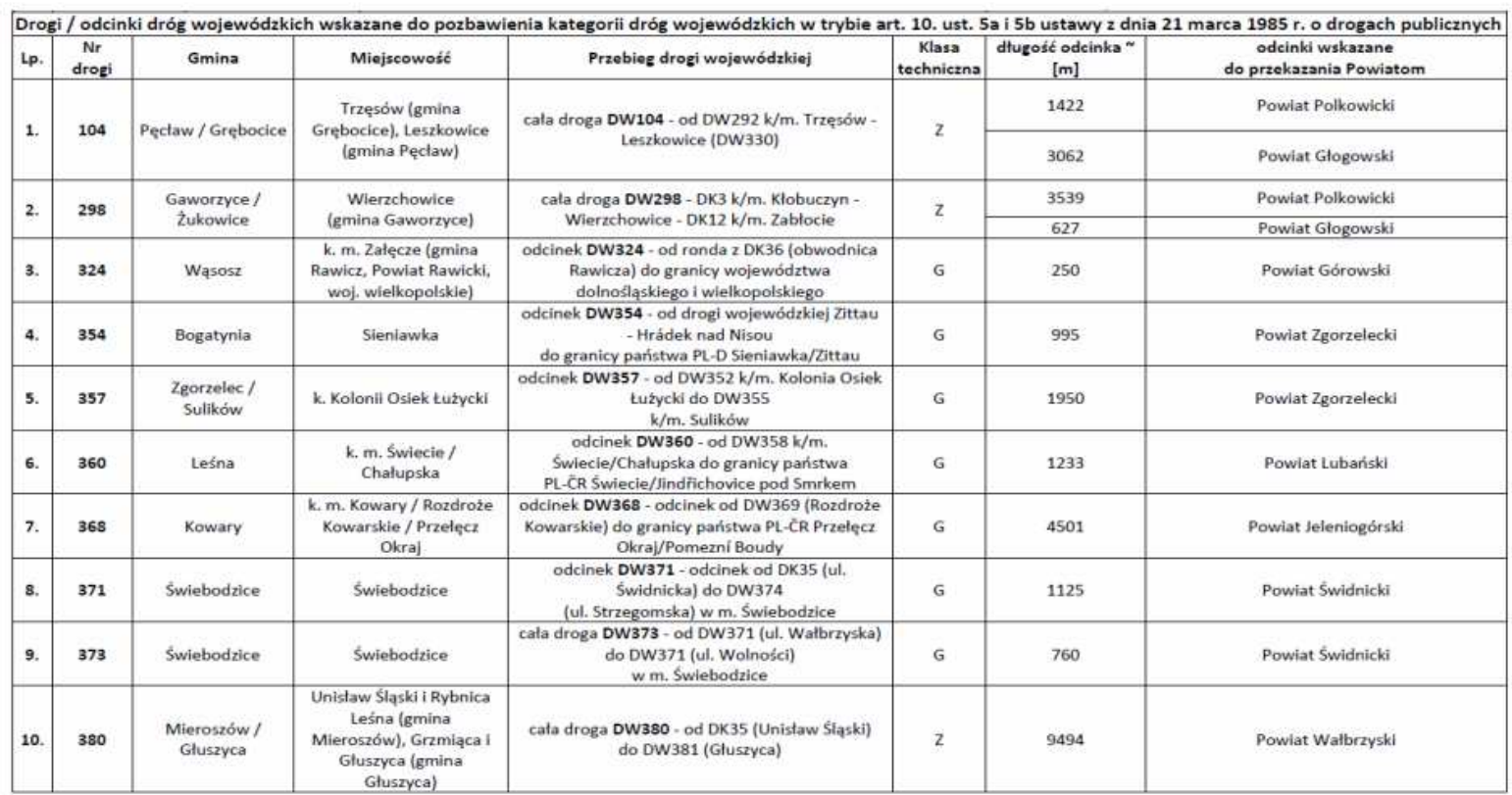


A very similar case took place in the Wielkopolskie Province, where the Pilski District appealed against the resolution No. XIV / 399/16, which was repealed by the verdict No. SA / PO 468/16 by the Provincial Administrative Court. The justification was very similar to that we could read from the judgment of the Wrocław court. The court first of all pointed to the lack of justification that these sections of roads no longer met the definition of provincial roads. Looking at subsequent resolutions regarding the transfer of provincial roads by both the provinces, improvement can be noticed in the Wielkopolska Region, where the justification is richer in arguments regarding the transfer of road sections, e.g. resolution No. XXVII / 730/17. In the case of the Lower Silesian Province, it is difficult to say whether the Council drew conclusions from the verdict of the Province Administrative Court, because the only resolution depriving the category of provincial road took place only six days later, which is the resolution No. XXV / 766/17 of 29 September 2017, is organized in the same way as previous resolutions regarding the transfer of roads, only a section of the road and length are given. However, there is no reason why a given section of road should be deprived of a category.

The resolutions and court judgments shows that the implementation of the cascade resolution makes the local government authorities quite difficult, because we can notice a number of applications from different districts to the province but also communes against districts, about law violations, mainly due to lack of argument for the transfer of roads. However, not all conflicts between individual self-government bodies ended in court.

\section{Possible arguments in the case of depriving traffic categories of road sections}

After analysing court judgments and resolutions, it can be stated that the most important element that a local government authority must fulfil is a good justification that the described road no longer meets the definition of provincial roads. This definition is given in the Act on public roads, Article 6, paragraphs 1 - 3 .

I believe that the best way to prove this is to analyse the course of a given route and traffic based on publicly available data, in order to be able to show that the road does not fulfil the function as provincial roads.

\section{Analysis of the route}

In this case, one should consider how the route goes and which its significance throughout the entire province is. According to the author, it is not possible to deprive the category of the road, which, despite the low traffic, connects two important communication nodes, or the capital of the province with district cities (on district law, and capitals).

However, it is possible to take into account sections of less important roads linking small municipalities, and capitals of district, which do not connect any significant transport hubs, or very poorly integrated into the whole provincial road network.

Of course, also the old roads received by the province, may not meet the definition of a provincial road and can be passed on, e.g. the old section of the national road in the district city, which has been replaced by the bypass.

\section{Traffic analysis}

According to the author, the analysis of the provincial road alone is not sufficient. The traffic that is observed on the analysed sections of the road should be taken into account. A very useful tool in this aspect may be the GPR - General Traffic Measure in the case of provincial roads, updated by GDDKiA every 5 years on national and provincial roads. The data contained in it can be very helpful in assessing the significance of a given section of the road for the province. For example, it can be used to determine what the general movement looks 
like on provincial roads and compare a given section to the average in the province in order to see how a given section changes over the region (Figure 1).

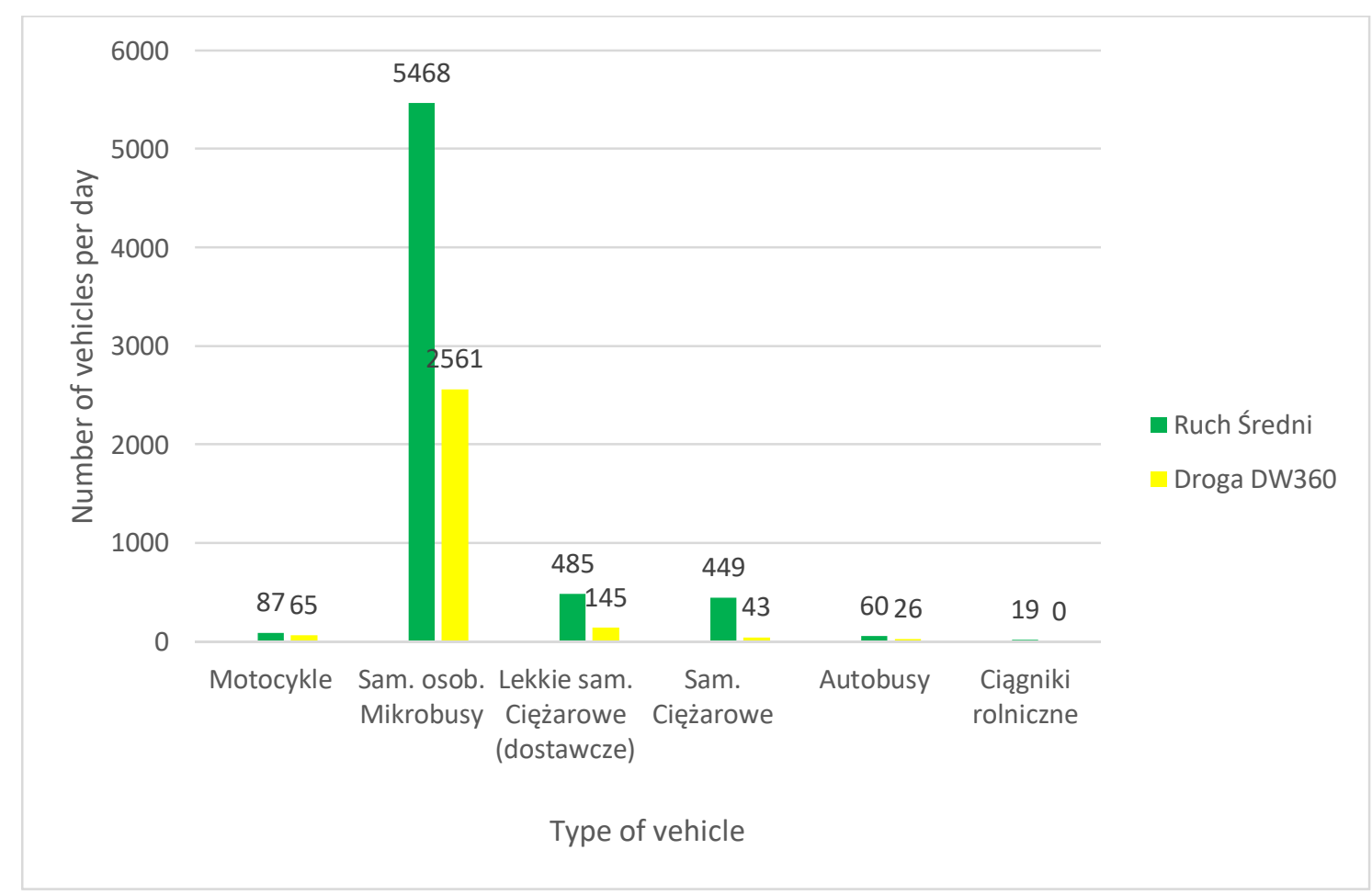

1. Comparison of medium traffic on provincial roads to DW360

Based on the above chart, it is possible to clearly and easily show how a given section is compared to the average in the entire province, which may be an argument when trying to deprive such a category of traffic.

No less important is the traffic structure itself. In this case, the only thing that is counted is not the number of vehicles on the road but their type. It should be stated, which type of vehicle best reflects the definition of a provincial road, e.g. agricultural tractors indicate the local character of the road, and how its share is presented on the average region and how it affects the nature of the road (Figure 2).

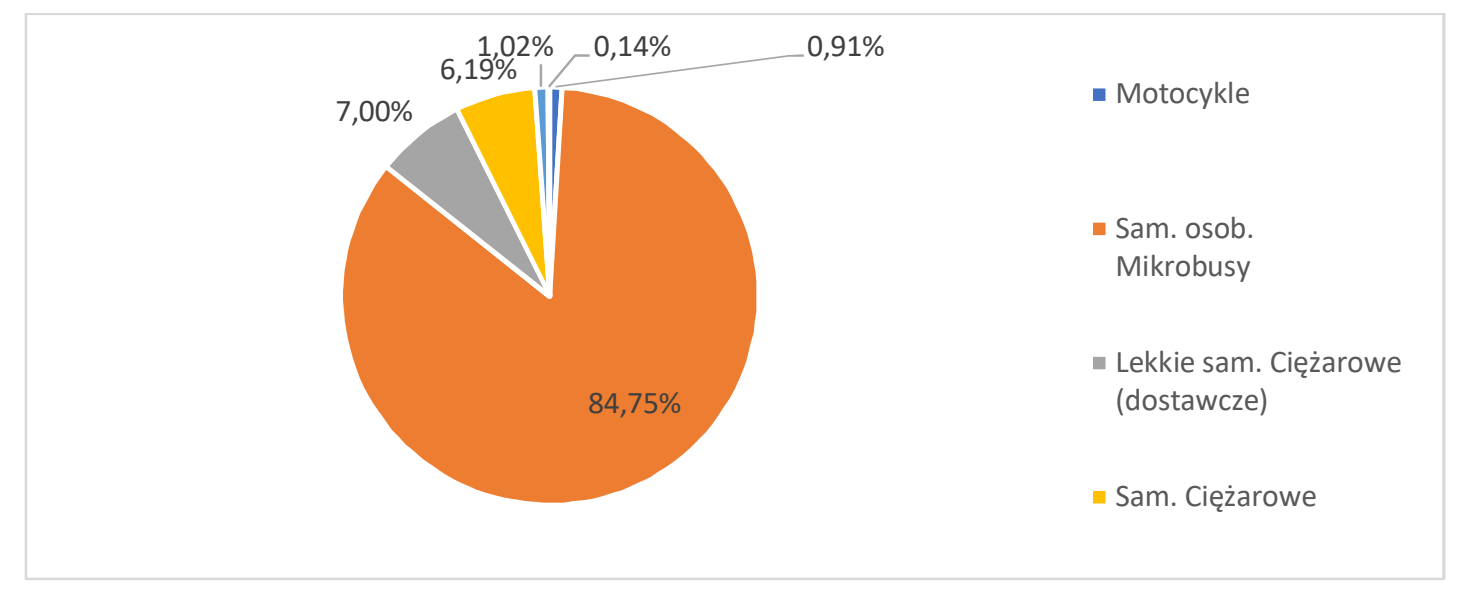

2. Distribution of various types of vehicles on DW455 
Other data that may be used to justify depriving the provincial road is to show the change in traffic on the given section in recent years and, for example, the decreasing number of vehicles, which may indicate a decrease in the importance of a given section for the road network (Figure 3).

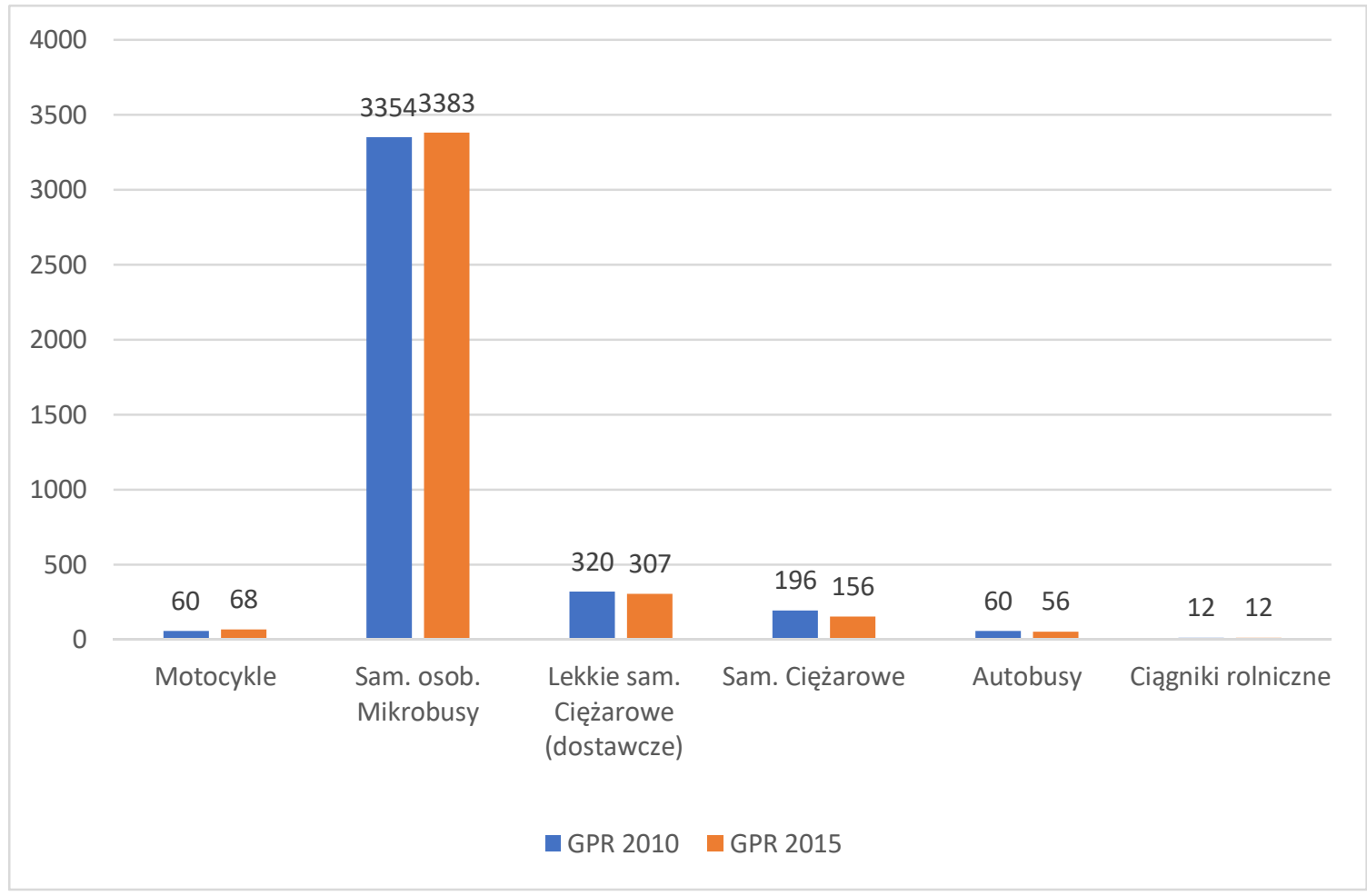

3. Change in traffic to DW392: Years $2010-2015$

For the analysis of whether a given road section still meets the assumed definitions, traffic forecasts for the future years may also be prepared. Then, on their basis, one can also draw conclusions on whether the analysed path can be deprived of category and transferred to lower self-government bodies.

The advice given on the analysis of sections of provincial roads can also be used in the analysis of district roads. It should be noted, however, that the measurement of traffic on district roads is not generally available, as information obtained from the General Traffic Measurement.

\section{Conclusions}

Based on the analysis of the resolutions, it can be concluded that the application of the socalled cascade law is still problematic for local government bodies. However, thanks to the guidelines that we can find in court judgments, you can find appropriate criteria to justify depriving a category of a given stretch of road. I would also like to point out that the analyses of provincial road data provided in the article may also be used in the case of district roads with similar problems.

\section{Source materials}

[1] Dziennik ustaw Rzeczypospolitej Polskiej, poz 870 z dnia 24.06.2015r.

[2] III SA/Wr 359/16 - Wyrok WSA we Wrocławiu z 23.09.2016 r. 
[3] Prawidłowe pozbawienie drogi dotychczasowej kategorii, Mateusz Karciarz, 17.01.2017, Prawo dla Samorządu.

[4] SA/PO 468/16 Wyrok WSA w Poznaniu z 16.02.2017 r.

[5] Uchwała $\mathrm{Nr}$ XIV/399/16 z dnia 25 stycznia 2016 r. Sejmiku Województwa Wielkopolskiego.

[6] Uchwała $\mathrm{Nr}$ XVI/428/15 z dnia 26 listopada 2015 r. Sejmiku Województwa Dolnośląskiego.

[7] Uchwała $\mathrm{Nr}$ XXV/766/17 Sejmiku Województwa Wielkopolskiego $\mathrm{z}$ dnia 29 września $2017 \mathrm{r}$.

[8] Uchwała $\mathrm{Nr}$ XXVII/730/17 Sejmiku Województwa Wielkopolskiego $\mathrm{z}$ dnia 28 lutego $2017 \mathrm{r}$.

[9] Ustawa z dnia 21 marca 1985 r. o drogach publicznych.

[10] Wyniki GPR 2010 na drogach wojewódzkich, GDDKiA.

[11] Wyniki GPR 2015 na drogach wojewódzkich, GDDKiA. 